\title{
Migrant rap in the periphery
}

\section{Performing politics of belonging}

\author{
Sirpa Leppänen \& Elina Westinen \\ University of Jyväskylä, Finland
}

\begin{abstract}
Focusing on a YouTube performance by an emergent Finnish Somali rapper and the audience responses it has generated, this paper looks at ways in which rap music engages with the issue of belonging. Drawing on recent theorizations of belonging as a multi-dimensional, contingent and fluid process, along with sociolinguistic work on globalization and superdiversity, Finnish hip hop culture and popular cultural practices in social media, the paper investigates how belonging is performatively and multi-semiotically interrogated in its online context. It shows how rap can serve as a significant site and channel for new voices in turbulent social settings characterized by rapid social change and complex diversity, as well as provide affordances for critical responses to and interventions into xenophobic and nationalist debates and discourses of belonging.
\end{abstract}

Keywords: Finland; hip hop culture; rap music; YouTube; migrants; blackness; belonging; multisemioticity; sociolinguistics

\section{Introduction}

Besides encompassing a global dimension, hip hop is always locally rooted and expresses itself with local linguistic, discursive and cultural means. In this paper, our focus is on such articulations of hip hop: we will discuss the case of emergent, Finland-based migrant rap and the ways it has given the marginalized and oppressed a voice to discuss not only personal but also societal issues and challenges (e.g. Rose, 1994; Mitchell, 2001). By migrant rap we mean here rap by artists who are first or second generation migrants, have no or one ethnic Finnish parent(s), and engage in their musical production with such issues as mobility, multiculturalism, ethnicity, race and discrimination. However, it should be noted that by using the notion of 'migrant rap' we are not suggesting that it is essentially different from other types of (Finnish) rap. Rather, this term helps us to emphasize 
that in the Finnish hip hop scene there are now emerging voices and discourses that have taken up and politicized Finnish rap in largely unprecedented ways.

Such voices have so far been marginal, but their ways of engaging in hip hop culture have now become more prominent and are gaining popularity more widely. The fact that such voices are now beginning to be heard is one indication of the rapidly changing and diversifying Finnish society. Compared to many other European countries, Finland has remained ethnically and culturally homogeneous for a long time (Häkkinen \& Tervonen, 2005). During the past 150 years, it has mostly been a country of emigration (Martikainen et al., 2013: 23). On a larger scale, immigration began in the early 20th century, with an acceleration after the end of the Cold War period, and, in particular, since the enlargement of the European Union at the turn of the millennium (Rapo, 2011). Up to 2010, the number of immigrants remained, however, very small. For example, in 1990, there were fewer than 110,000 'foreign' inhabitants in Finland. After this period, the number of persons born outside Finland has grown considerably so that in 2014, their percentage was already c. 5.0. By 2010, most of the immigrants had come from the neighboring countries, while the rest had come from Asian countries, Somalia and Europe. Currently, the refugee crisis is changing the situation again, with 32,476 people seeking asylum in Finland in 2015 (cf. 3,651 in 2014) (Ministry of the Interior, n.d.). Because of these processes, Finland is now shifting towards a more multiethnic and multicultural society - decades later than many other European countries. These changes have also triggered strong antiimmigration reactions (Martikainen et al., 2013: 37-38), ranging from xenophobic and protectionist public debates to highly derogatory and discriminatory discourses of the ethnic and/or migrant other, and to tightened government asylum policies and measures.

In this changing societal, political and discursive context, migrant rappers and the perspectives and stories they offer highlight both individual and more collective experiences and interrogations of how migrants can find their home in a society that has not been accustomed to, but now definitely needs to come to terms with difference and diversity. Significantly, they have begun to ask questions such as who may belong where, how, and on what grounds - and who gets to decide. In these ways, the new voices and discourses of rap in Finland have also become a channel through which issues and articulations of (in)equality and belonging have become more widely heard.

In focussing on such articulations of emergent voices of rap, our paper will contribute to research on migrant rap that is still largely absent in Finland (but see Kärjä, 2011; and Westinen, 2016, 2017). Specifically, we will investigate the case of Bizzyiam, a young Finland-based rap artist with a Somali background. As an example of new migrant rap, we will discuss how in, and in responses to, one 
of his very first rap videos, he and his online audiences negotiate belonging. With the help of this case, we show how in the changing Finnish society rap can serve as a crucial means for identification, self-expression and protest, as well as for creating affordances for critical responses to and interventions into xenophobic and nationalist debates and discourses of belonging. In so doing, we also hope to contribute to the themes of the special issue and to highlight how mediatized practices of migrant rap can bring about new meanings about who can belong to a society that has long defined and upheld a notion of belonging as deriving from ethnic, Finnish-speaking white mono-cultural Finnishness.

As our data we will use a rap video, "Maan tavalla" ('When in Rome, do as the Romans do') by Bizzyiam, ${ }^{1}$ along with the viewer comments it has generated. Drawing on recent sociolinguistic work on globalization and superdiversity (e.g. Blommaert, 2010; Pennycook, 2007; Blommaert \& Rampton, 2011), Finnish hip hop culture (Westinen, 2014; see also Kalliokoski 2006; Leppänen \& Pietikäinen 2010) and popular culture on social media (Leppänen et al. 2014), we will examine the multisemiotic (linguistic, discursive, cultural, embodied, cinematic and aural) resources the rap performance draws on. We will show how, through the mobilization of these resources, Bizzyiam creates a multi-voiced and stylized performance, highlighting how 'belonging to' a society and culture means reflexive and relational acts of meaning making in which perspectives and positions of the mainstream ethnic Finns and those of migrants intersect, contrast and blend. In our investigation of the audience comments, in turn, we will look at the impact that Bizzyiam's performance has had, and how it has served the audiences as a means for appreciating and learning more about diversity and marginality, while it has also triggered contestations and denials of migrants' right to belong. Before the detailed analysis of these data, we will, however, first briefly discuss the concept of belonging, and the history and nature of Finland-based rap.

\section{Belonging as a multifaceted process}

We conceptualize belonging as a multifaceted process involving social, discursive and affective dimensions. Its social dimension has to do with how it is a socially constructed, embedded process in which people "reflexively judge the suitability of a particular site as appropriate with respect to their social trajectory and their position in other fields" (Savage et al. 2005: 12). This sense of belonging

1. Bizzyiam has given us a permission to use the particular music video and lyrics as our data in this paper. 
encapsulates how people may (or may not) feel at home in any one place, relating this to the habitus and capital of its residents (ibid.). In this (sociological) sense, belonging also entails "one's practical cognitive and affective sense of who one is, of one's social location, and of how (given the first two) one is prepared to act" (Brubaker \& Cooper, 2000: 17). Thus, belonging also relates to subjectivity and agency (Bell, 1999: 1), to the degree in which individuals may and are able to identify with particular sites and people.

The discursive sense of belonging entails two interrelated dimensions. Firstly, it is a discursive process in that it is semiotically constructed and negotiated in discourse. It involves particular choices of language and other semiotic resources, acts and patterns of interaction, as well as activities in which specific understandings of belonging are suggested and negotiated in situated ways. Belonging is discursive also in the sense that it involves the ways in which we construct ourselves and others in different discourse contexts (Yuval-Davis, 2006: 199; Lehtonen \& Löytty, 2003: 12; Leppänen et al., 2017). At the same time, it is also discursive in the Foucauldian sense in that it is concerned with such questions as:

[...] what makes us who we are within a particular social complex, and how are we to understand ourselves, our politics, our desires and our passions as produced within this historical present. Thus, the concern is with the ways in which technologies, discursive deployments and power/knowledge networks produce the lines of allegiance and fracture in the various orders of things within which people and objects move.

(Bell, 1999: 1)

Technologies, discourses and power/knowledge networks position individuals at the intersection of specific possibilities and constraints for aspiring for and claiming belonging. They are also part of constellations of regulation and policing of belonging, some of which may take the form of codified norms and regulations and which may vary in terms of their reach and generality (cf. Lähdesmäki et al., 2014: 96).

The affective dimension of belonging, in turn, means that it is about "emotional attachment, about feeling 'at home' and [...] about feeling 'safe" (YuvalDavis, 2006: 197). Its affectivity also derives from the ways in which it is seen and experienced in relation to both from where one comes, and possible future states of belonging to which one may aspire (Savage et al., 2005; Probyn, 1996; Fortier, 2000). It thus involves longing and desire to belong, "a tenacious and fragile desire that is $[\ldots]$ increasingly performed in the knowledge of the impossibility of ever really and truly belonging, along with the fear that the stability of belonging and the sanctity of belonging are forever past" (Probyn, 1996: 8).

Belonging is a crucial question in the late modern world of mobilities and diversities that "multiply interactions with others not personally known", and place 
us in situations in which "occasions for identification are particularly abundant" and require individuals to consider ways how "one identifies oneself and how one is identified by others" (Brubaker \& Cooper, 2000: 14). To vulnerable and disenfranchised individuals and groups the questions where and in what ways they can and may belong are particularly acute ones. A case in point is migrants. For them, the possibilities of, obstacles to and grievances related to belonging are of importance, and these are often challenged and questioned in various ways (Eliassi, 2010: 89; Krzyżanowski \& Wodak, 2008). For many of them, this means that they need to engage with the politics of belonging as a crucial part of their lives. These politics can include particular political projects aimed at constructing belonging to (a) collectivity(ies) (such as racialized projects of nation building), which are themselves being constructed in these projects in very specific ways and with very specific boundaries, but they also involve more personal identity politics, and participatory politics of citizenship, entitlement and status (Yuval-Davis, 2006).

For our purposes, belonging serves as a key analytic coordinate. For emergent migrant rappers, belonging serves as an epistemological and discursive tool for interrogating the ways in which they and others like them are, on the one hand, forced in material, political and discursive ways into marginality in the increasingly xenophobic Finnish society, and, on the other hand, for articulating their own possibilities, experiences and desires related to belonging.

\section{Peripherality, centrality and Finnish hip hop}

As a wealthy, technologically advanced and relatively equal society, Finland cannot really be considered occupying a position of economic, social or cultural marginality (e.g. Jokinen et al., 2004). However, with respect to the world system (e.g. de Blij, 2008), it could be argued to be situated in 'the periphery of the center' (Lehtonen \& Löytty, 2007: 110). It is part of the Northern and Western 'center', a member of the European Union and part of the Trans-Atlantic 'West'. At the same time, within this center, it has a peripheral status, due to its geographical location - far up in the arctic North and close to the (Russian) East -, its small population and economy, as well as the direction of cultural flows that has long tended to be dominated by influences from the outside. Its geographical, demographic, socioeconomic and cultural peripherality is also reflected in the belittling image that Finns often project about themselves (Lehtonen \& Löytty 2007: 111).

Also Finnish hip hop is, in a sense, located at the periphery of the center. As in many other parts of the world, it has been inspired by and developed according to the models suggested in its 'original center' - African-American, AfroCaribbean and Puerto Rican youth culture of DJs, MCs, breakdancing and graffiti 
(Rose, 1994: 2, 34). In the mid-1970s, this center for hip hop was in New York City and South Bronx: they provided fertile ground "for the birth of a revolutionary cultural movement called hip hop" (Price, 2006: 4).

A couple of decades later, hip hop had spread across the globe. In Mitchell's words (2001: 1-2), it can no longer be "viewed simply as an expression of African American culture; it has become a vehicle for global youth affiliations and a tool for reworking local identity all over the world". Its current globality is emphasized by such concepts as the "Global Hip Hop Nation", "a multilingual, multi-ethnic 'nation' with an international reach, a fluid capacity to cross borders, and a reluctance to adhere to the geopolitical givens of the present" (Alim, 2009: 3). In this sense, hip hop has no clear center any more. Rather, it is a network through whose nodes transcultural flows traverse and in which cultural forms "change and are reused to fashion new identities" in such processes of cultural production as "borrowing, blending, remaking and returning" (Pennycook, 2007: 6-8).

With respect to the overall view of hip hop as a transnational, rhizomatic and 'hydrological' complex, Finnish hip hop has, nevertheless, remained peripheral. This is because, until fairly recently, it has not engaged in substantial ways in collaboration with scenes and actors elsewhere; and, except for a few notable exceptions, not many Finnish rap artists are known outside the national borders (Westinen, 2014). Moreover, Finnish rap has been relatively homogeneous in that it has been dominated by the voices of ethnic Finns.

At the same time, as a node in the rhizome of global hip hop, Finnish hip hop could be seen to constitute a center in its own right that has furnished itself "with a hip hop history and ideology that demarginalizes [it] and situates [it] squarely in the center" (Omoniyi, 2009: 122). For example, local rap artists continually posit and construct Finland and Finnish hip hop as 'centers', by not only highlighting Finland and the excellence of Finland's rap music and artists, but also by problematizing and addressing its local and national issues.

\section{Finnish hip hop and rap: A brief introduction}

Hip hop culture arrived in Finland from the United States in the 1980s. Initially, breakdance and graffiti were the most visible and popular activities of the culture. Gradually, however, also rap music began to gain more popularity. Its first wave in the 1980s and -90s was characterized by Finnish-language rap. Due to its long distance from the mother country of rap it tended to be humorous and parodic in nature, while the second wave at the turn of the 21st century was marked by big record labels and mainstream successes, as well as by a linguistically heterogeneous style combining resources from Finnish and English. Its third wave in the 2010s (Kärjä, 2011; Westinen, 2014) has involved the increased diversification, popularity 
and visibility of hip hop culture and rap music. This diversity shows, most significantly, in the multiplication of the scene: there are now numerous styles and themes. At the same time, the Finnish hip hop scene has also remained a closeknit one, with contacts and collaboration between the actors within and across the different scenes. That rap is now a significant and meaningful music genre in Finland (Westinen, 2014) is testified, in turn, by the visibility of (some) rappers in the mainstream media, the number of live gigs and of the digital downloads and radio plays of their pieces. Thus, nowadays, rap has established itself amongst other genres of popular music, but what also characterizes it are the ways in which its borders are increasingly porous, with a great deal of musical mixing and crossing taking place. Linguistically, however, Finnish rap is nowadays more unified, with Finnish used, in fact, much more commonly than English (Westinen, 2014).

\section{The emergence of migrant rap}

Migrant rap artists are newcomers onto the Finnish scene (but not entirely without antecedents; Mikkonen, 2004), with first active and more prominent artists emerging in the beginning of the 2010s. In this, Finland is lagging behind many other European countries. Unlike in, for example, France (Prévos, 2001) and Germany (Androutsopoulos, 2010) in which migrant rap has always been an integral part of the local scene(s), in Finland migrant rappers continue to be few. Currently, there are only a dozen active ones. Often they are also considered 'exotic exceptions' who stand out from the rest of the (white, ethnic Finnish) rap scene.

For migrant youth, (American) hip hop culture, with its emphasis on locality and blackness, can serve as a 'natural' and attractive gateway to rap (Lankinen, 2015: 278). In this respect, hip hop culture is much more welcoming to black and colored youth than many other music cultures. For example, (heavy) metal, another highly popular music culture in Finland (ibid.: 289-290), is both performed and appreciated by white people. The close connection between hip hop and urban American street culture also provides migrant rappers with a positive and empowering black model. As such, and in contrast to the image that is often highlighted in Finnish public discussions (Lankinen, 2015: 279; Eronen et al., 2014), it generally does not highlight migrants (particularly of African origin) as an uneducated, unemployed, and potentially crime-inclined group (see e.g. Halonen, 2009).

Linguistically, however, the positive models provided by urban American street and hip hop cultures to migrant rappers no longer seem to involve much (African American) Vernacular English (AAVE). While at first most of them chose English as their rap language, more recently many artists have tended to use mostly Finnish in their art. Interestingly, and perhaps as an attempt to ensure communication with the mainstream Finnish-speaking audiences, most of these 
rappers very seldom use resources provided by any other languages, even though many of them have a versatile linguistic repertoire.

However, due to the relative whiteness of Finnish society, popular culture and hip hop, the emergent black artists need to negotiate their role and status in the already established scene. While doing so, they also 'talk back' (hooks 1989) from their marginalized minority positions. In this task, many of them have resorted to humor and parody as ways to discuss otherness and ethnic stereotypes in their musical production (Westinen, 2017). What is perhaps less common is a 'serious' take on contemporary societal political issues such as (anti)racism and multiculturalism. ${ }^{2}$ In this respect, Bizzyiam is an interesting example, for he aims at an almost real-time discussion of events and issues that have raised a lot of controversy in the Finnish society. His case thus illustrates how rap can successfully combine and integrate both serious and entertaining aims.

\section{Performing a politics of belonging: The case of Bizzyiam}

Bizzyiam (Hassan Maikal) ${ }^{3}$ (b. 1996) is a second-generation Finnish Somali rap artist (Rautio, 2016; Valkonen, 2015). He began rapping in 2015, immediately publishing his first song "Ongelmii on" ('I've got problems') on YouTube. Since then, he has been very prolific as a (local) cultural actor: in addition to his rap activities, he works as a host, producer and vlogger $<$ www.hassanmaikal.com $>$.

Among migrants of African descent (currently c. 30,000), Somalis are the biggest African diaspora group in Finland. As part of the now quite visible minority, they have contributed to the on-going change of the Finnish society and culture in various ways (Rastas and Seye, 2016: 83). In the current anti-immigration climate in the country, they, however, often face discrimination and racism, and have few opportunities to be heard in public discussions on racism and racialized relations (Rastas, 2012, 2014). Nevertheless, within the migrant groups in Finland, Somalis are among the most politically active: they are keen voters and participants in organizations and community-level activism (Pirkkalainen et al., 2016: 69). Bizzyiam is no exception in this respect: the two music videos (along with his

2. A dozen Finnish rap artists recently joined forces in a song "Räppärit rasismia vastaan" ('Rappers against racism') (2015), which takes a strong stand against the polarized attitudinal climate in contemporary Finland.

3. In 2017, Bizzyiam started using his given name as his artist name. In this article, we, however, refer to him as Bizzyiam since it was the name he used when publishing the song under investigation. 
other video clips on YouTube) he has already published can all be regarded as forms of political activism.

Like many other emergent rappers, Bizzyiam has used social media as a channel for disseminating and promoting his work. His trajectory from a local actor, performing to his friends or in school events, to a more generally recognized 'new' voice in Finnish rap has been a quick one. In using social media platforms as venues for his performances and interactions with his audiences, Bizzyiam is, in fact, part of a trend whereby social media function both as a popular 'stage' for lay and celebrity performances and as 'a virtual lounge' for audience reactions to and evaluations of these performances (Marwick \& boyd, 2011). On YouTube, as an example of 'produsage culture' (Bruns, 2008), performances are disseminated for appreciative audiences who, in turn, take up what is being performed in discussions and debates, but also in replications and recontextualizations of different kinds and degrees of appreciation and criticality (Bolter \& Grusin, 2002; Häkkinen \& Leppänen, 2014; Leppänen \& Elo, 2016). YouTube is thus not simply a medium in which people watch videos, listen to music, broadcast their own videos (see e.g. Burgess \& Green, 2009), but it also provides a forum for DIY cultures, cultural niches and memes to breed, multiply and diversify.

For migrant Finnish rappers, YouTube has also become a means of reaching audiences beyond their locality. For many young artists, their mediatized performances have proved an important means for establishing their artist identity and authenticity, and for generating more followers and fans (Westinen, 2016, 2017; Karrebæk et al., 2015). Social media performances are also something that these artists can themselves monitor, and thus they provide them with an opportunity to a voice that can have considerable reach and potential in terms of audience engagement.

The video ${ }^{4}$ under investigation in this paper consists of a performance of Bizzyiam's song "Maan tavalla" (literally: '[when in a country,] you need to act according to the customs of the country; idiomatically: 'When in Rome, do as the Romans do.'). Except for a few English lines, the song is in vernacular Finnish, indicating that it is explicitly aimed at Finnish-speaking audiences. In fact, Bizzyiam's language choice is already an indication of belonging - for him, the natural choice for his art is Finnish, not English or Somali. After its publication on YouTube in February 16, 2016, the video has attracted a great deal of attention: at the time of writing this (May 26, 2017), it has been viewed 43,826 times. Shortly after its publication, also several national newspapers got interested in Bizzyiam and

4. The video was produced and directed by Samer Qaraman (b. 1997), a young high school graduate and photographer. 
interviewed him, which further contributed to the song and the video reaching a wider audience.

What inspired Bizzyiam was a verbally racist attack by an ethnic Finnish woman against a Finnish Kenyan woman. ${ }^{5}$ This verbal attack, in which the Finnish woman chose to use English, was filmed and published by the victim on social media. It immediately became a topic for heated debates and discussions. The insults by the Finnish woman were also taken up by Bizzyiam, and he used them to begin and complete his song. By so doing, he immediately indicated to his Finnish audiences the motivation and starting point for the song - the increasingly frequent explicitly racist incidents in Finland.

Next, we will turn to the analysis of Bizzyiam's music video. We will pay particular attention to the use and interplay of different semiotic resources in the video and the ways in which they draw on available associations and discourses and evoke particular meanings related to belonging. More specifically, our investigation will focus on the cinematic representation of the figure of this young black man, his embodied and musical actions, and the discourse of the song (for more details on multisemiotic analysis of social media discourse, see Leppänen et al. 2014; Leppänen \& Kytölä, 2017). After this, turning to the audience commentary of the video, we will investigate how they take up and discuss Bizzyiam's interrogation of belonging, and the kinds of more general discussions of belonging the video stimulates.

\section{Rap performance as politics of belonging on the stage of social media}

By deploying a variety of semiotic resources, Bizzyiam uses the affordances provided by rap music, the genre of music video and YouTube as a platform to interrogate belonging as a complex and shifting notion.

\section{Belonging as emplacement and emotional attachment}

The video begins with a sequence of shots depicting Bizzyiam in- and outside what looks like a traditional Finnish summer cottage in the middle of a snowy forest. The quiet wintery location symbolizes the 'new' home of the black man, embodied by Bizzyiam's solitary figure, as a cold, peripheral country where, instead of people, he is surrounded by snow and trees (see Image 1):

5. <http://www.iltalehti.fi/uutiset/2015102420553621_uu.shtml> 


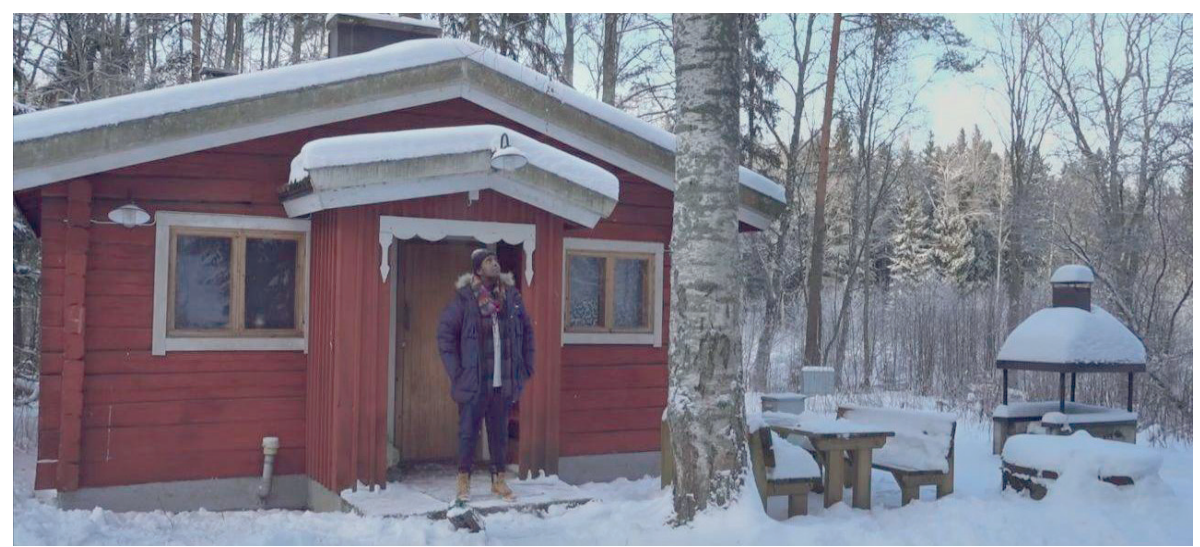

Image 1. Bizzyiam in front of a summer cottage

Next, the video depicts Bizzyiam in a study, engaged in thinking (Image 2):

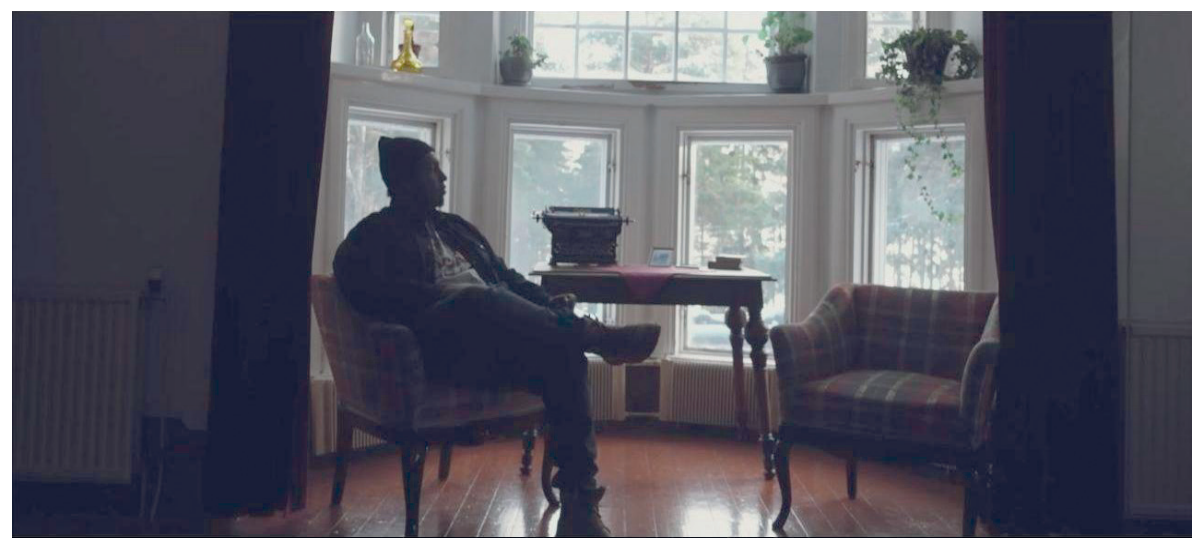

Image 2. Bizzyiam engaged in thinking in a study

After this, the next scene presents him on an empty stage in an old theatre, both with and without an audience (Images 3 and 4).

Visually, the first scenes of the video highlight the loneliness, isolation and brooding of the young black man - he is on his own in landscapes and spaces without any possibility of real interaction with other people. The fact that his loneliness is repeatedly emphasized in the video suggests that his performance is really about his individual thoughts, dreams and fears and attempts at coming to terms with his difference in the 'cold' and (literally, ethnically) white Finnish society - voicing his reflections to us through his monologic rap. 


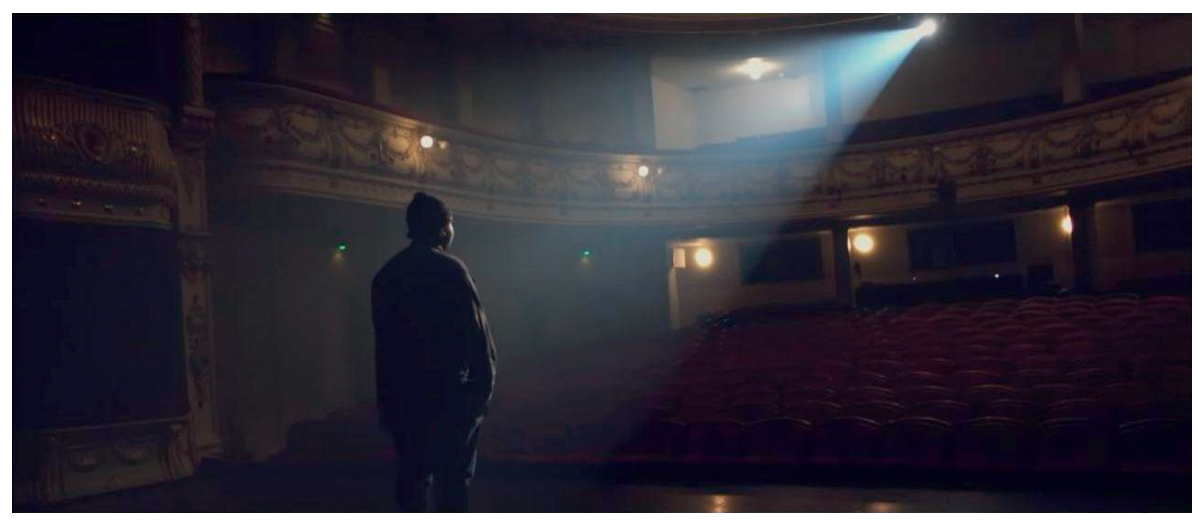

Image 3. Bizzyiam in an empty theatre

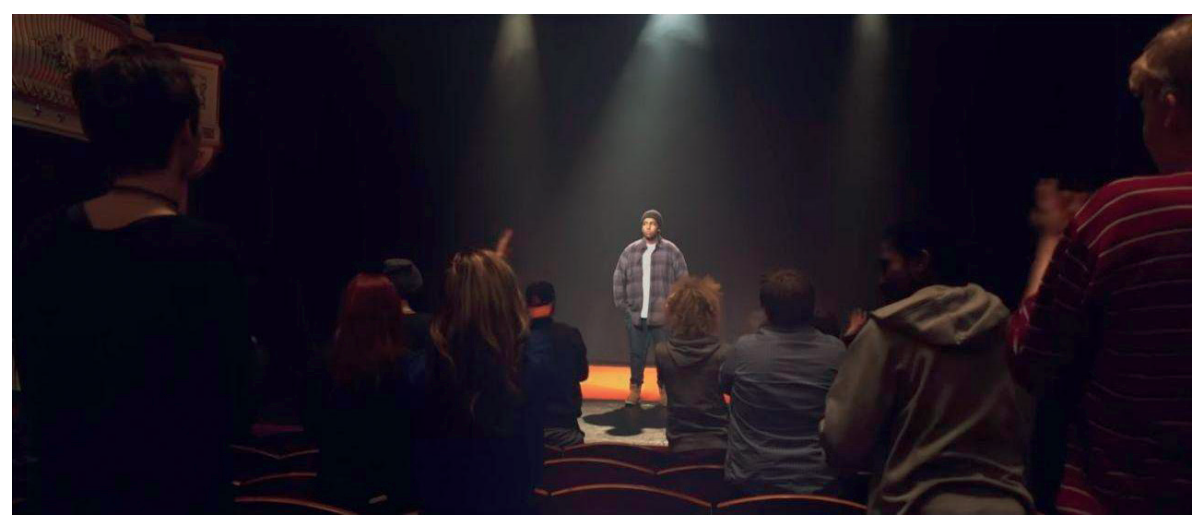

Image 4. Bizzyiam in front of an audience

\section{The (im)possibility of social belonging}

At the same time, the emphasis on Bizzyiam as the solitary focus for the audience gaze conveys a sense of the near impossibility of social belonging. The images emphasize, quite simply, that there really is no one else available with whom to identify. The scenes depicting him on a stage convey a sense that he is, nevertheless, exposed to scrutiny by others - alone, performing to a faceless, unknown audience. The affectivity of the cinematic representation in the video is thus very clear, and it is also emphasized by the text that suggests that he does not belong to Finland and wishes to escape from it ("enkä tiedä minne mennä pakoon" - 'and I don't know where to escape').

The impossibility of social belonging is, in fact, a central theme of the video. Besides the evocative images, the video also depicts black men as having personal 
ambitions and dreams of becoming an important and accepted part of the society. For example, both the lyrics and the images highlight such dreams - dreams of becoming 'the president, doctor, or policeman' (see Image 5).

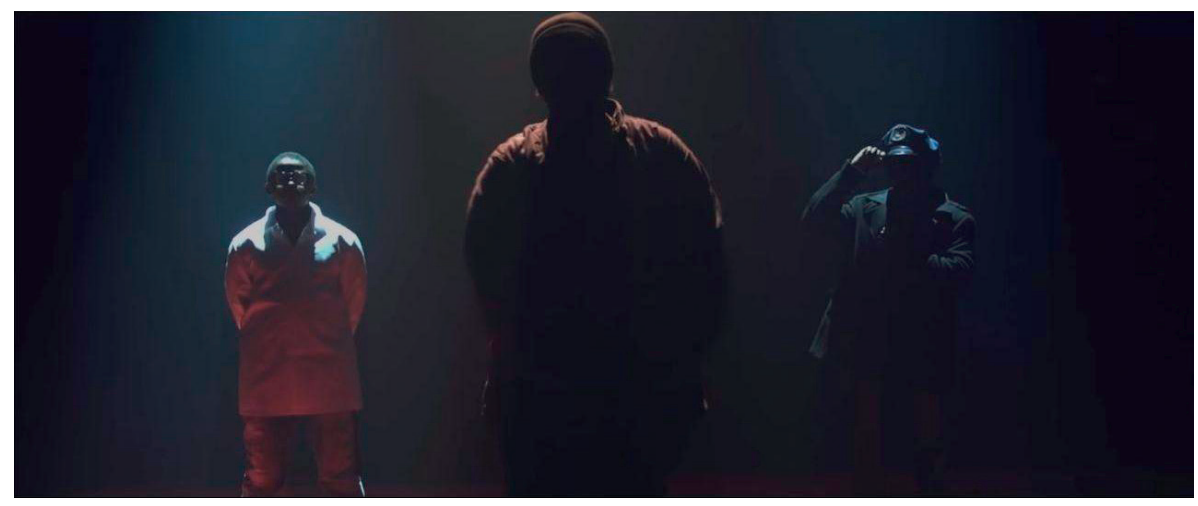

Image 5. Black men: the doctor, the president and the police officer

Nevertheless, these images are shown to be without much grounding. The clearest example of this is the way in which the video refers to the polarization and hostility of Finnish society and its people. For instance, the beginning of the video with the audio sample voicing the racist insults by the Finnish woman (beginning with "you are ZERO..."; Image 6) makes it clear that, as far as the white society is concerned, the only position available for black people like Bizzyiam is in the margins (if even there; see below).

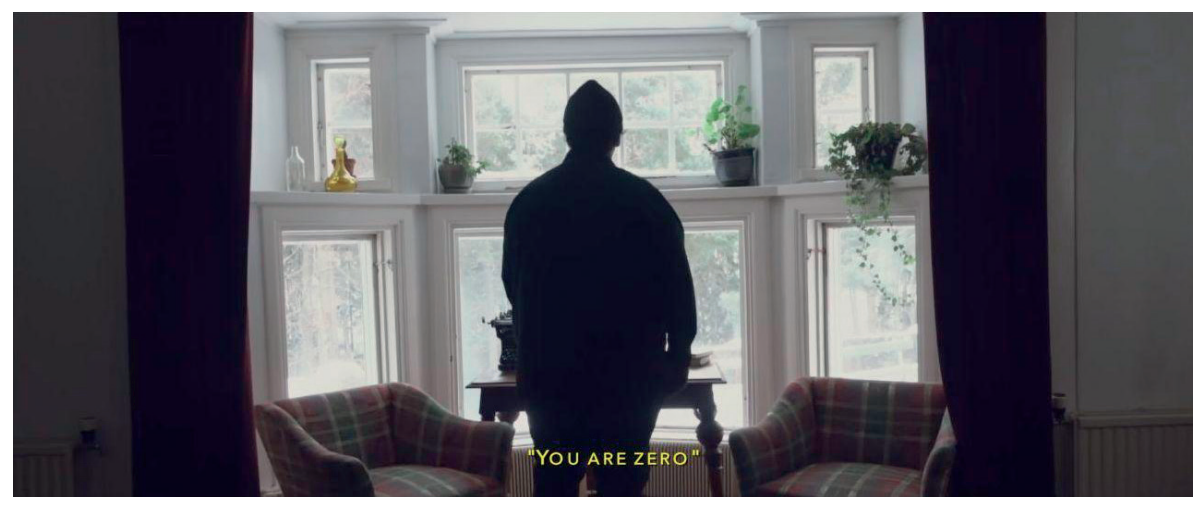

Image 6. The framing racist commentary

What also drives home the position of marginality are the references in the song to places and occupations that are taken to be suitable for the black: kitchen work and cleaning. 


\section{Extract 1.}

Original lyrics: ${ }^{6}$

Isomies nii nyt nää kelaa et oon kylän kokkii

Soppii en tee, pastat vetee

Tartun mun moppiin ja alan pesee
English translation (by SL \& EW):

A big man, so they assume that

I'm the village chef

I won't make soups, put pasta in the water

I grab my mop and start cleaning

In these ways, the video suggests how black people are not granted the right to fully belong by the mainstream white society. This is also emphasized by the way the lyrics refer to those who have the political power in the country and who either do not seem to care ('politicians throwing dice'), or whose politics is aggressively anti-immigration. For instance, the song refers to the populist party The Finns and its power: "The true Finland under Halla-aho'7 ("Perus Suomi Halla-ahon alla") implying that theirs is the kind of Finland to which Bizzyiam and others like him are not welcome to belong.

While the video represents the figure of the black man as someone who cannot and may not belong to the nation of Finland, as a rapper, he is perfectly at home. Despite the fact that he is not placed in the stereotypical 'home' of hip hop, the inner city and its streets (see e.g. Forman, 2002) and that he performs without such customary aspects of hip hop as homeboys or posses, he seems completely at home. While rapping, he is often smiling, seeking to engage with the viewers via a direct eye contact. Also his rhythmic moves and gestures, in tune with the recognizable rap beats, along with his baggy hip hop style of clothing are all strongly suggestive of Bizzyiam's identification with and belonging to hip hop culture.

\section{Engagement with discourses of belonging}

In its interrogation of belonging, the video also recontextualizes aspects of discourses about Finnishness and Finnish culture. By mobilizing such discourses, Bizzyiam thus indicates that he is aware of the cultural features and practices that Finns hold valuable, while also conveying a sense that these are not seen by others as belonging to someone like him. For example, the video includes references

6. The original lyrics and their English translation can be found in the appendix.

7. 'The true Finland' refers to the Finnish-language name of the party, perussuomalaiset, roughly translatable as 'True' Finns; Halla-aho is currently (as of 2017) the chair of this populist party and a member of the European Parliament. He has become known for his blog in which he vehemently criticizes multiculturalism and integration policies and advocates for a strict immigration policy. 
to such iconic aspects of Finnish culture as the high value attached to spending time in nature, the summer cottage and sauna (see e.g. Simula, 2012), as well as to such staple Finnish products as dark rye bread. That the indices of Finnish culture zoomed on the video do not, however, belong to the black man is repeatedly emphasized by the chorus of the song, as follows:

\section{Extract 2.}

Maasta maahan tai maassa maan tavalla Saarest saaree oon kylmän ilman alla Enkä tiedä minne mennä pakoo En haluu eksyy kylmää rakoo

When in Rome do as the Romans do From an island to another, I'm under cold air And I don't know where to escape I don't want to get lost in this cold hole

In other words, the video emphasizes that, even though the black man has acquired the knowledge of key aspects of Finnishness and is aware of the expectations voiced in the Finnish proverb 'maassa maan tavalla' ('When in Rome..') - that he should follow the customs of the country and be 'integrated', he is constantly reminded of the impossibility of this task. He remains 'under cold air' and does not 'want to get lost in this cold hole' - an outsider who does not want to identify with what still appears to him as foreign and unwelcoming.

The video also makes use of one of the grand narratives of the Finnish nation the Second World War. This it does by showing us a black man engaging in military action in a uniform dating back to the time of the Second World War (see Image 7).

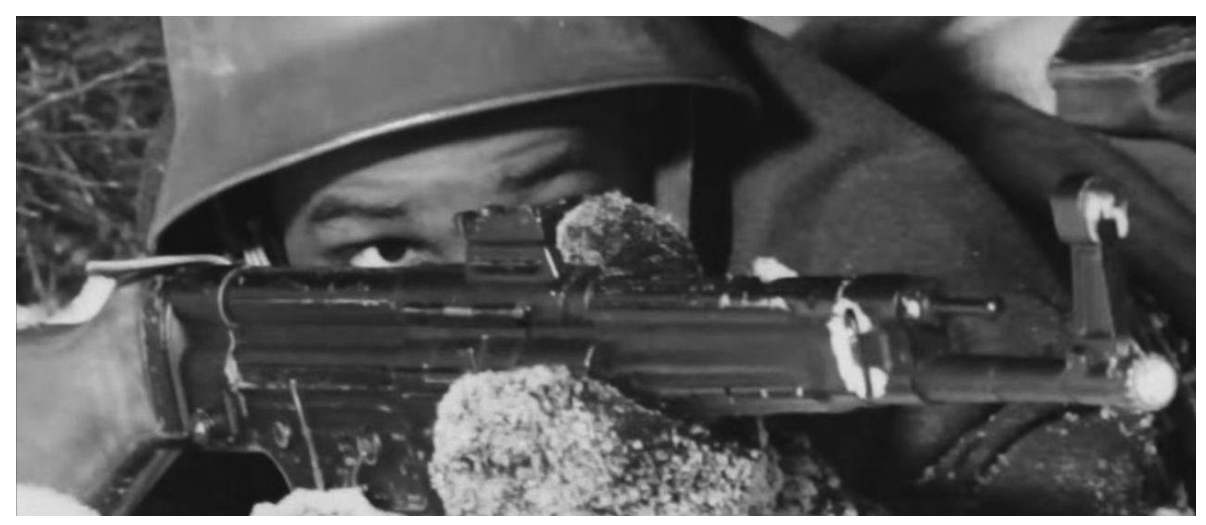

Image 7. A black man in the 'Winter War'

The imagery here implies the Finnish Winter War (1939-40) which is often referred to as the historical moment in which the nation was unified against the common enemy, the Soviet Union. By placing the black man in the context of the narrative of national unity and heroism, the video, at first glance, seems to suggest 
that also black Finns could be seen as equally patriotic and legitimate members of the nation as ethnic Finns. Nevertheless, this message is presented to us ironically. For example, the soldier's helmet is worn backwards, and the pipe of his gun is blocked. In addition, the lyrics subvert the first impression suggested by these images: they imply how the (discourses of the) wonderful homeland can make the black man lose his sanity:

\section{Extract 3.}

Tämä suomen somali tulee sotii sun sotiisi Mustat miehet öisin suksilla sotimaan Oi meidän ihana Suomi kotimaa

Kotimaa kullan kallis, sekottaa sunki nallis

This Somali Finn will come to fight in your wars In the night, black men ski to make war Oh our wonderful Finland the homeland The homeland more precious than gold, it will mix up your head, too

\section{The ultimate denial of belonging}

The prejudices and denials referred to in the lyrics and the video not only imply that black people have no right to belong to the society, but that they do not even belong to the human race. As pointed out above, the video begins with the audio and subtitles of the racist attack by a Finnish woman: "You are zero, you are not human, in my eyes". This racist comment thus sets the tone for the entire video. The lyrics also describe black people as equated to rats, monkeys and dogs - all references that radically de-humanize them. At the end of the video, the racist woman is quoted again: "You are welcome, but not in my country" which once more underlines the assertion that black people are not allowed to belong to white Finnish society.

The culmination of this kind of exclusion is the presentation of black people as the enemy in the video. Towards its ending, we are given a cinematic depiction of white hands lighting a Molotov cocktail, followed by the sound of breaking glass, clearly suggesting that the threat of violence is never far as a means of rejecting, terrorizing and pushing black people away from the society that is implied to belong to the whites only.

Both the beginning and the end of the video thus show that black people are denied by the white mainstream society the right to belong. They are not considered members of the society, or even of the human race. The overall message of the video is, in this sense, an utterly pessimistic one, suggesting how belonging for the likes of Bizzyiam is nearly impossible. At the same time, and significantly, Bizzyiam's interrogation of belonging is not entirely pessimistic. This is because, the performance - Bizzyam's choice to compose and present his song, in Finnish, to Finnish audiences, and by incorporating a racist Finnish voice in it - is in itself a political act. Through his reflection and presentation of the impossibility of 
belonging to the white society, he asserts that he is still hoping to belong to the community of those who are willing to listen to him.

\section{Audience reactions - demarcating the right to belonging}

The audience responses to Bizzyiam's video show that he has indeed been heard. This is evident in the number of viewers and likes the video has had (43,826 views and 1039 likes by May 26, 2017). Despite his status as a newcomer, he has managed to attract a large audience. The audience has also given him a great deal of verbal feedback, 136 comments by the time of writing this. As is often customary on YouTube, the commentary does not, however, include any extensive discussion or exchanges between the posters, but most of the comments are short one-liners. Nevertheless, the comments show that his audience is, for the most part, a positive and encouraging one. For example, he receives a great deal of digital cheering and applause, some of which are only conveyed via emojis. The comments also show that his audience is a Finland-based one - they are mainly written in Finnish, although there are a few in English and Somali, too. At the same time, the commentary the video has received also indicates that his audience is not a homogeneous group but includes different subgroups.

One of these groups are those who apparently know Bizzyiam and cheer him as their local idol. For example, comments such as 'hey, this turned out to be really good!' ("tostahan tuli hyvä!!”) show that the person has heard about the song/ video project already prior to the publication and wants to show their knowledge of and support for the cause. Such commentary thus showcases Bizzyiam's belonging to a local group where he is appreciated and supported.

Some participants in the local groups are clearly quite close to Bizzyiam ("Well done Hassan! keep doing what you're doing cuzzy, love from all of us!"). Indeed, some of the comments make it clear that, like the poster of the comment, he belongs to the Somali community in Finland: 'Bre, give it your best shot somali like me' ("Bre pistä parastas somppu niiku mä”). These posters thus emphasize that Bizzyiam is their 'brother' ("bre" is a local slang version of 'bro') and belongs to the group of Somalis and acts as their mouthpiece.

Yet another group of commentators are those who constitute a new audience whom the video and Bizzyiam's visibility in other media or other (physical) performances has managed to reach and win over. Such responses are exemplified by comments like: 'I’m so stunned the song is just amazing!!!!! WOW' ("kyllä nyt löi ällikällä aivan huikee biisi!!!!! WOW”) and 'I see a lot of fucking potential in this!' ("Nään vitusti potenttiaalii täs!"). Such commentary mainly seems to recognize that Bizzyiam, because of his excellence, has managed to break through to the Finnish music scene. 
Some members of Bizzyiam's YouTube audience indeed ratify him as someone who has gained the right to belong to the Finnish hip hop scene. Thus, his piece is, for the most part, appreciated. In line with the ethos of playful/serious competitiveness of rap, his skills are praised for being better than other Finnish rap artists' (who are white), for example the highly popular, mainstream success Cheek (see Westinen, 2014): 'Now Cheek takes second place. :D' ('Ny jäi Cheekki kakkoseks.:D”), or the 'humor' rapper Petri Nygård: 'You (sur)passed Petri nygård' ("Ohitit kyl Petri nygårdii"). However, his competence is also questioned by some commentators. He is claimed to have 'stolen' the chorus from a song by the same name by a Finnish reggae artist Raappana (although, in actual fact, Bizzyiam made it quite clear that he had been granted the permission to use the sample in his song). Some posters are also quite dismissive about his music, and simply reject it as 'Piece of dirt' ("Aikamoista kuraa").

Finally, Bizzyiam's audience also includes a small group who post hostile and aggressive comments. Such racist commentary highlights the view that Bizzyiam, and others like him, simply 'do not belong here'. For the most part, what we see is a recycling of similar racist arguments that are also voiced in the lyrics of the song, in the form of orders such as 'go home' ("mee kotias") as well as name calling and attributes (characterizing Bizzyiam with the n-word, calling black people and migrants rapists, or labelling them as inherently bad, lazy and violent). Some of the comments also highlight hierarchies of belonging: those who adapt well to Finland are welcome, whereas those who do not, are not tolerated. This can be seen, for example, in the following comment: 'I wish it was 'when in Rome' here, too and these people wouldn't behave like animals. They should learn our culture and manners before they come here' ("olisipa maassa maan tavalla tälläkin eikä nää käyttäytyis kuin eläimet. Oppisivat kulttuurin Ja tavat ennekuin tulee tänne”). In the same way as the illustration of racist attitudes in the song, such a comment is, allegedly, made from a position of power, moralistically criticizing and dehumanizing (black) migrants. In some comments we see even more detailed hierarchic evaluations of difference. For example, a poster states that: '... the people coming from Asia are the best immigrants I know!' (“... nämä Aasiasta tulevat ovat parhaita maahanmuuttajia, mitä tiedän!”), thus implying that black or Somali immigrants are in fact below Asians in the hierarchy of 'welcome immigrants'. In this respect, the hostile audience responses resemble the hate discourse in 'immigration critical' social media sites which voice increasingly aggressive, violent and degrading attitudes directed at immigrants, refugees and people with a migrant background (see e.g. Horsti 2015). Significantly, out of all migrant groups, people with a Somali-background constitute the group that receive the most and most serious hate discourse (Ministry of Justice Report, 2016: 71; Pöyhtäri, Haara, \& Raittila, 2013: 106).

However, many of the racist comments on Bizzyiam's video are quickly taken up and challenged by others. This is done, for instance, by counter-attacks which 
are also racist. For example, these include insults like the following, directed at a critical commentator who is assumed to be an Arab: 'you just keep on selling kebab and cutting hair you don't have what it takes to be a rapper $\mathrm{xD} \times \mathrm{xD}$ ' (“jatka sinä kebabin myymistä ja karvojen leikkaamista ei susta ole räppäriksi $\mathrm{xD}$ $\mathrm{xD} \mathrm{xD}$ "). The derogatory comments are also challenged by demands that the critics themselves 'make a better [rap song]' as they probably cannot do 'shit but call black people names' and by suggestions that 'it is easy to write racist comments behind an alias' ("rasistisia kommentteja on helppo huudella anonyyminä"). Some of the commentators even state that it is, in fact, the racists who do not belong 'here', 'here' extending from the YouTube site to hip hop, Finland, the world at large, and even the human race. For instance, such views are illustrated by the following two comments: 'You're a dickless clown, hopefully some day you will develop into a human being' ("Olet munaton pelle, toivottavasti vielä joku päivä kehityt ihmiseksi") and 'There is no place for people like you in this country or in the world. I hope you understand that and choke on your narrow-mindedness' ('Sinunlaisille ei ole tässä maassa eikä maailmassa paikkaa. Toivottavasti ymmärrät sen ja tukehdut ahdasmielisyyteesi”).

Put together, the comments on Bizzyiam's performance clearly indicate the importance of social media as fora for cultural practices: they allow the display and sharing of cultural products, their active uptake and dialogue and exchange between audience members. For beginning artists, such as Bizzyiam, they offer an opportunity to perform to audiences which he possibly would not be able to reach otherwise. Most importantly, with respect to the focus in this paper, Bizzyiam's performances and audience engagement can show some of the impact of his interrogation of belonging. In his case, the primarily positive reception of his performance ends up showing that, while it discusses the difficulties and tensions that black migrants have in seeking, finding and being granted belonging in society, through the sharing of his art, another dimension of belonging becomes possible, a dimension that is less burdened by tensions. In this sense, his rap could be seen as a liminal space (Bhabha 2004) which is, at least momentarily, outside the oppressive impossibility of belonging, and inside the realm of hope that his voice can make a difference.

\section{Conclusion}

In this article, we focused on rap in the periphery of global hip hop culture, as performed by an emergent Finland-based, migrant black rapper, Bizzyiam, and investigated the ways in which his rap and its uptake by audiences engaged with the question of belonging. We argued that rap can become a space for interrogating experiences, emotions and discourses related to belonging. We emphasized 
how it can serve as a significant channel for new voices in turbulent and diversifying social settings, and provide affordances for critical responses to and interventions into xenophobic, racist and nationalist debates and discourses of belonging.

Using a dramatized version of one of Bizzyiam's recent songs and the comments it triggered on YouTube as our data, we showed how the mediatized performance constitutes a politics of interrogation of belonging - a means for identification, self-expression and protest - that is meaningful not only for Bizzyiam himself, but also for others sharing his social and cultural location. We demonstrated how his performance creates a multi-voiced and stylized performance of belonging highlighting how 'belonging to' society and culture means reflexive and relational acts of meaning making in which perspectives and positions of the mainstream ethnically Finnish population and those of migrants intersect, contrast and blend. More specifically, guided by recent theorizations of belonging, our analysis of the various semiotic resources mobilized in the video showed how Bizzyiam's performance constructed a multi-faceted picture of the tensions and challenges that black migrants face in terms of belonging to the national and ethnic collectivity of Finland. It showed their lack of feeling at home and safe, their loneliness and isolation, the impossibility of their social belonging, the lack of available subject positions for them in the discourses of the white nation, and the ways in which in both their everyday lives and in national politics they are faced with practices and discourses of exclusion, marginalization and de-humanization.

However, besides this image emphasizing non-belonging, we discovered that both the video and its uptake also point to the existence of yet another, and less oppressive, dimension of belonging. On the one hand, this is evident in Bizzyiam's performance that is aimed at and addresses Finnish-speaking rap audiences. It also shows in the way it functions as an act of identification with others who find hip hop and rap as meaningful and significant cultural practices, and who are open to messages conveyed by new voices, regardless of whether or not they belong to the majority of ethnic Finns. On the other hand, the audience comments testify that his voice is in fact heard and that it has power to influence others. While the commentary includes some racist and derogatory posts that recycle more widely circulating discourses of non-belonging, most of the posts do highlight that Bizzyiam, a black migrant, is taken as a member of various local groups - that of local friends, fans and supporters, of Finland-based Somalis and (possibly other migrants), of the local music scene and, in particular, of the Finnish hip hop scene and culture. Thus, our observations also highlighted what Urry (2000: 132-133) has identified as a facet of belonging, how it "almost always involve(s) diverse forms of mobility', so that people dwell "in and through being at home and away, through the dialectic of roots and routes". 
Finally, our analysis identified some potential for change, too: Bizzyiam's case gives us a complex, nuanced analysis of the possibilities and desires of belonging. In these ways, it could be argued, Bizzyiam's performance has served the audiences as a means for appreciating and learning more about diversity and marginality. In line with earlier findings on migrant rappers (Westinen, 2016), it could be argued that also Bizzyiam's video and its uptake evince how rap and its mediatized performances serve as a "third space" (Bhabha, 1994) in which artists can deliberate their belonging, often with others like them, as well as with people who understand them and sympathize with them. In these ways these migrant rap artists can thus be seen as providing 'new' and critical perspectives on and embodiments of Finnishness (see also Oikarinen-Jabai, 2013; Rastas \& Päivärinta, 2010; Westinen $2016,2017)$. In addition to pondering on their own individual lives and problems, they raise awareness on the larger-scale issues of migration, racism and diversity.

\section{References}

Alim, H. S. (2009). Introduction. In H. S. Alim, A. Ibrahim \& A. Pennycook (Eds.), Global linguistic flows. Hip hop cultures, youth identities, and the politics of language (pp. 1-22). New York, NY: Routledge.

Androutsopoulos, J. (2010). Multilingualism, ethnicity and genre in Germany's migrant hip hop. In M. Terkourafi (Ed.), Languages of global hip hop (pp. 19-43). London: Continuum.

Bell, V. (1999). Performativity and belonging: An introduction. In V. Bell (Ed.), Theory, Culture \& Society: Performativity and belonging (pp. 1-10). London: Sage. doi:10.4135/9781446219607.n1

Bhabha, H. K. (2004). The location of culture. London: Routledge.

Blommaert, J. (2010). The sociolinguistics of globalization. Cambridge: Cambridge University Press. doi:10.1017/CBO9780511845307

Blommaert, J., \& Rampton, B. (2011). Language and superdiversity. Diversities, 13(2), 1-20.

de Blij, H. (2008). Power of place: Geography, destiny, and globalization's rough landscape. Oxford: Oxford University Press

Bolter, J. D., \& Grusin, R. (2002). Remediation: Understanding new media. Cambridge, MA: The MIT Press.

Brubaker, R., \& Cooper, F. (2000). Beyond “identity". Theory and Society, 29, 1-47. doi:10.1023/A:1007068714468

Bruns, A. (2008). Blogs, wikipedia, second life, and beyond from production to produsage. Bern: Peter Lang.

Burgess, J., \& Green, J. (2009). YouTube. Online video and participatory culture. Cambridge: Polity Press.

Eliassi, B. (2010). A stranger in my homeland. The politics of belonging among young people with Kurdish backgrounds in Sweden. Unpublished PhD dissertation, Mid Sweden University, Östersund, Sweden. <http://miun.diva-portal.org/smash/get/diva2:337597/FULLTEXT01. pdf> (10 December, 2016). 
Eronen, A., Härmälä, V., Jauhiainen, S., Karikallio, H., Karinen, R., Kosunen, A., Laamanen, J-P., \& Lahtinen, M. (2014). Maahanmuuttajien työllistyminen. Taustatekijät, työnhaku ja työvoimapalvelut. Helsinki: Työ- ja elinkeinoministeriö. < http://www.tem.fi/files/40368/ maahanmuuttajien_tyollistyminen.pdf. 17.6.2016>

Forman, M. (2002). The hood comes first. Race, space and place in rap and hip-hop. Middletown, CT: Wesleyan University Press.

Fortier, A. -M. (2000). Migrant belongings. Oxford: Berg.

Häkkinen, A., \& Leppänen, S. (2014). YouTube meme warriors: Mashup videos as political critique. In J. Tyrkkö \& S. Leppänen (Eds.), Texts and discourses of new media. eVarieng 15. $<$ http://www.helsinki.fi/varieng/series/volumes/15/> (12 December, 2016).

Häkkinen, A., \& Tervonen, M. (2005). Johdanto. In A. Häkkinen, P. Pulma, \& M. Tervonen (Eds.), Vieraat kulkijat - tutut talot. Näkökulmia etnisyyden ja köyhyyden historiaan Suomessa (pp. 7-36). Helsinki: Suomalaisen kirjallisuuden seura.

Halonen, M. (2009). Islam alakoulussa: Koulu kaksisuuntaisen sopeutumisen kenttänä. Nuorisotutkimus, 27(3), 33-46.

Horsti, Karina. (2015). Techno-cultural opportunities: the anti-immigration movement in the Finnish mediascape. Patterns of Prejudice, 49(4), 343-366. doi:10.1080/0031322X.2015.1074371

hooks, b. (1989). Talking back: Thinking feminist, thinking black. Cambridge, MA: South End Press.

Jokinen, A., Huttunen, L., \& Kulmala, A. (Eds.). (2004). Puhua vastaan ja vaieta. Neuvottelu kulttuurisista marginaaleista. Helsinki: Gaudeamus.

Kalliokoski, J. (2006). "Omaa panosta omasta vokabulaaristosta." Rap-tekstit stadin slangin kuvina. In K. Juusela \& K. Nisula (Eds.), Helsinki kieliyhteisönä (pp. 299-317). Helsinki: Helsingin yliopisto.

Kärjä, A-V. (2011). Ridiculing rap, funlandizing Finns? Humour and parody as strategies of securing the ethnic other in popular music. In J. Toynbee \& B. Dueck (Eds.), Migrating music (pp. 78-91). London: Routledge.

Karrebæk, M. S., Stæhr, A., \& Varis, P. (2015). Punjabi at heart: Language, legitimacy, and authenticity on social media. Discourse, Context \& Media, 8, 20-29.

doi:10.1016/j.dcm.2015.05.007

Krzyżanowski, M., \& Wodak, R. (2008). Multiple identities, migration and belonging: 'Voices of migrants'. In C. R. Caldas-Coulthard \& R. Iedema (Eds.), Identity trouble: Critical discourse and contested identities (pp. 95-119). Houndmills: Palgrave Macmillan.

Lankinen, N. (2015). "Mun veris on gängstaa.” Somalialaistaustaisen helsinkiläistytön tyylilliset käytänteet. In M. -L. Sorjonen, A. Rouhikoski, \& H. Lehtonen (Eds.), Helsingissä puhuttavat suomet. Kielen indeksisyys ja sosiaaliset identiteetit (pp. 267-293). Helsinki: SKS.

Lehtonen, M., \& Löytty, O. (2003). Miksi Erilaisuus? In M. Lehtonen \& O. Löytty (Eds.), Erilaisuus (pp. 7-17). Tampere: Vastapaino.

Lehtonen, M., \& Löytty, O. (2007). Suomiko toista maata? In J. Kuortti, M. Lehtonen, \& O. Löytty (Eds.), Kolonialismin jäljet. Keskustat, periferiat ja Suomi (pp. 105-118). Helsinki: Gaudeamus.

Leppänen, S., \& Elo, A. (2016). Buffalaxing The other: Superdiversity in action on YouTube. In K. Arnaut, J. Blommaert, B. Rampton, \& M. Spotti (Eds.), Language and Superdiversity (pp. 110-136). New York, NY: Routledge. 
Leppänen, S., \& Kytölä, S. (2017). Investigating multilingualism and multisemioticity as communicative resources in social media. In M. Martin-Jones \& D. Martin (Eds.), Researching multilingualism: Critical and ethnographic perspectives (pp. 155-171). New York, NY: Routledge.

Leppänen, S., Kytölä, S., Jousmäki, H., Peuronen, S., \& Westinen, E. (2014). Entextualization and resemiotization as resources for identification in social media. In P. Seargeant \& C. Tagg (Eds.), The language of social media: Identity and community on the internet (pp. 112-136). Houndmills: Palgrave Macmillan. doi:10.1057/9781137029317.0010

Leppänen, S., Kytölä, S., Westinen, E., \& Peuronen, S. (2017). Introduction: Social media discourse, (dis)identifications and diversities. In S. Leppänen, E. Westinen, \& S. Kytölä (Eds.), Social media discourse, (dis)identifications and diversities (pp. 3-35). New York, NY: Routledge.

Leppänen, S., \& Pietikäinen, S. (2010). Urban rap goes to Arctic Lapland: Breaking through and saving the endangered Inari Sámi language. In H. Kelly-Holmes \& G. Mautner (Eds.), Language and the market (pp. 148-158). Houndmills: Palgrave Macmillan.

Lähdesmäki, T., Ahvenjärvi, K., Hiltunen, K., Jäntti, S., Sääskilahti, N., \& Saresma, T. (2014). Mapping the concept(s) of belonging. In S. D. B. Picken \& J. Platt (Eds.), Conference Proceedings: The Fourth Asian Conference on Cultural Studies 2014 (pp. 85-99).

Marwick, A., \& boyd, d. (2011). To see and be seen: Celebrity practice on Twitter. Convergence: The International Journal of Research into New Media Technologies, 17(2), 139-158

Martikainen, T., Saukkonen, P., \& Säävälä, N. (2013). Muuttajat. Helsinki: Gaudeamus.

Mikkonen, J. (2004). Riimi riimistä. Suomalaisen hiphopmusiikin nousu ja uho. Helsinki: Otava.

Ministry of the Interior. (n.d.). Turvapaikanhakijoita saapui viime vuonna ennätysmäärä. <http://www.intermin.fi/fi/maahanmuutto/turvapaikanhakijat> (27 June, 2016).

Ministry of Justice Report. (2016). Selvitys vihapuheesta ja häirinnästä ja niiden vaikutuksista eri vähemmistöryhmiin. Oikeusministeriön julkaisu, 7.

Mitchell, T. (Ed.). (2001). Global noise. Rap and hip-hop outside the USA. Middletown, CT:Wesleyan University Press.

Oikarinen-Jabai, H. (2013). Finnish youth with Somali background performing their experiences and belongings. In To be young! Youth and the future. <https://www.utu.fi/fi/yksikot/ ffrc/julkaisut/e-tutu/Documents/eBook_2013-8.pdf> (17 December, 2015).

Omoniyi, T. (2009). "So I choose to do am Naija style" - Hip hop, language, and the postcolonial identities. In H. S. Alim, A. Ibrahim, \& A. Pennycook (Eds.), Global linguistic flows. Hip hop cultures, youth identities, and the politics of language (pp. 113-135). New York, NY: Routledge.

Pennycook, A. (2007). Global Englishes and transcultural flows. London: Routledge.

Pirkkalainen, P., Wass, H., \& Weide, M. (2016). Suomen somalit osallistuvina kansalaisina. Yhteiskuntapolitiikka, 81, 69-77.

Prévos, A. (2001). Postcolonial popular music in France. Rap music and hip-hop culture in the 1980s and 1990s. In T. Mitchell (Ed.), Global noise. Rap and hip-hop outside the USA, pp. 39-56. Middletown, CT: Wesleyan University Press.

Price, E. G. (2006). Hip hop culture. Santa Barbara, CA: ABC-CLIO.

Probyn, E. (1996). Outside belongings. New York, NY: Routledge.

Pöyhtäri, R., Haara, P., \& Raittila, P. (2013). Vihapuhe sananvapautta kaventamassa. Tampere: Tampere University Press. 
Rapo, M. (2011). Kuka on maahanmuuttaja? Statistics Finland. <http://www.stat.fi/artikkelit/ 2011/art_2011-02-15_003.html> (28 March, 2016).

Rastas, A., \& Päivärinta, J. (2010). Vastapuhetta afrikkalaisten diasporasta Suomessa. Kulttuurintutkimus, 27(4), 45-63.

Rastas, A. (2012). Reading history through Finnish exceptionalism. In K. Loftsdottir \& L. Jensen (Eds.), 'Whiteness' and postcolonialism in the Nordic region (pp. 89-103). Burlington, VT: Ashgate.

Rastas, A. (2014). Talking back: Voices from the African diaspora in Finland. In M. McEachrane (Ed.), Afro-Nordic landscapes: Equality and race in Northern Europe (pp. 187-207). New York, NY: Routledge.

Rastas, A., \& Seye, E. (2016). Music as a site for Africanness and diaspora cultures: African musicians in the white landscape of Finland. African and Black Diaspora: An International Journal, 9(1), 82-95. doi:10.1080/17528631.2015.1055652

Rautio, S. (2016). Nosteessa-artisti Bizzyiam esiintyi uransa toisella keikalla Sauli Niinistölle: "Se tuli aivan puskista". YleX. <http://yle.fi/ylex/uutiset/nosteessa-artisti_bizzyiam_esiintyi_ uransa_toisella_keikalla_sauli_niinistolle_se_tuli_aivan_puskista/3-8699075> (7 June, 2016)

Rose, T. (1994). Black noise. Rap music and black culture in contemporary America. Hanover, NH: Wesleyan University Press.

Savage, M., Bagnall, G., \& B. Longhurst. (2005). Globalization and belonging. London: Sage.

Simula, M. (2012). Luonnossa liikkumisen kulttuuriset representaatiot: Diskurssianalyysi suomalaisten luonnossa liikkumista käsittelevistä haastatteluista. Unpublished $\mathrm{PhD}$ disssertation, University of Jyväskylä, Jyväskylä, Finland. Studies in Sport, Physical Education and Health 182.

Valkonen, T. (2015). Kulttuurit kohtaavat nuorten rap-työpajoissa. <https://www.thl.fi/fi/web/ maahanmuuttajat-ja-monikulttuurisuus/-/kulttuurit-kohtaavat-nuorten-rap-tyopajoissa>

Westinen, E. (2014). The discursive construction of authenticity: Resources, scales and polycentricity in Finnish hip hop culture. Unpublished PhD dissertation, University of Jyväskylä, Finland. <https://jyx.jyu.fi/dspace/handle/123456789/43614> (December 16, 2016).

Westinen, E. (2016). Multiscalarity and polycentricity in rap artists' social media communication: Multisemiotic negotiations of otherness and integration. In J. D. D. Singh, D. Cserző \& A. Kantara (Eds.), Downscaling culture: Revisiting intercultural communication (pp. 280-310). Newcastle upon Tyne: Cambridge Scholars.

Westinen, E. (2017). "Still alive, nigga." Multisemiotic constructions of self as the Other in Finnish rap music videos. In S. Leppänen, E. Westinen, \& S. Kytölä (Eds.), Social media discourse, (dis)identifications and diversities (pp. 335-60). New York, NY: Routledge.

Yuval-Davis, N. (2006). Belonging and the politics of belonging. Patterns of Prejudice, 40(3), 197-214. doi:10.1080/00313220600769331 


\section{Appendix}

\section{The lyrics of "Maan tavalla" ('When in Rome')}

Original lyrics by Hassan Maikal

A Finnish woman on a viral video:

You are ZERO

You are not human, in my eyes

You know what happened in OUR country

Why all come rape our country

\section{Bizzyiam:}

Chorus: Maasta maahan tai maassa maan tavalla

Saarest saaree oon kylmän ilman alla Enkä tiedä minne mennä pakoo

En haluu eksyy kylmää rakoo

Chorus

Yo, pitäiskö mua kaduttaa

Enkä tiedä pitäiskö unelmiani saavuttaa

Saavuttaa vaikkei ne saavukkaa

Oon mustamies vaik tuut pintaaniki

raavuttaa

Must tulee presidentti, lääkäri, poliisi

tämä suomen somali tulee sotii sun sotiisi

Mustat miehet öisin suksilla sotimaan

Oi meidän ihana Suomi kotimaa

Kotimaa kullan kallis, sekottaa sunki nallis

Jos et oo valkonen nii siivo oma tallis

Emmä haluu teit syyttää...

Mä oon musta nii tiedän et oon syypää

Tarinoit nää marinoi

$\mathrm{Ne}$ on erilaisii ne on apinoit

Maasta maahan tai maassa maan tavalla

Perus Suomi Halla-Ahon alla

$2 \times$ Chorus

Tiedon meri ei lopu mihin ranta

Kaulan ympärillä panta hei syvä santa

Fiilis niiku uppois mut kuuntelisko muit

Mua yrittää ohjaa aina monii eri suit

Kuljet muiden peräs nii ku sokee lammas

FREEZE

Nosta kädet ylös ja todista sunki kantas

Ku päättäjät ne heittää lähiklubil noppii

Ja me ollaa muka yhteiskunnan rottii

Dj paina stoppii nyt nää venaa jotai droppii

Isomies nii nyt nää kelaa et oon kylän kokkii

Soppii en tee, pastat vetee
Lyrics translated to English by SL \& EW

A Finnish woman on a viral video:

You are ZERO

You are not human, in my eyes

You know what happened in OUR country

Why all come rape our country

Bizzyiam:

Chorus: When in Rome do as Romans do

[literally: From a country to another, or live in the country according to its customs]

From an island to another, I'm under cold air

And I don't know where to run away

I don't want to get lost in this cold hole

Chorus

Yo, should I feel sorry

I don't know if I should fulfill my dreams

Fulfill them although they aren't there

I'm a black man even when you come and scratch my surface

I will become the president, doctor, police

This Somali from Finland will join your wars

In the night, black men ski to make war

Oh our wonderful Finland the homeland

The homeland more precious than gold, it will mix up your head, too

If you are not white you need to clean up

your own house

I don't want to blame you...

I'm black so I know I'm to blame

Their stories they marinate

They are different they are monkeys

When in Rome, do as the Romans do

The True Finland under the rule of Halla-aho

$2 \mathrm{x}$ Chorus

The sea of knowledge doesn't end in any shore

Around my neck a band, hey deep sand

I feel like drowning but should I listen to others

So many mouths try to guide me

You follow others like a blind sheep

FREEZE

Lift your hands and testify your belief

When the politicians throw dice in the club nearby

And we're supposed to be the rats of this society

Dj press stop now they wait for some drop

A big man so they take me for the local chef

I make no soup, put pasta in water 
Appendix (Continued)

Original lyrics by Hassan Maikal

Tartun mun moppiin ja alan pesee $8 \times$ Chorus

The migrant woman's voice from the viral video:

Thank you

The Finnish woman's voice from the viral video:

You're welcome

But not in my country...
Lyrics translated to English by SL \& EW

I take my mop and start cleaning $8 \times$ Chorus

The migrant woman's voice from the viral video:

Thank you

The Finnish woman's voice from the viral video:

You're welcome

But not in my country... 